\title{
Eco-Etnoturism: An Option for Sustainable Environmental Management
}

\author{
Emérita Sofía Muñoz Estrada ${ }^{\# 1}$, Mirian Muñoz Estrada ${ }^{\# 2}$, Katy Cecilia Herrera ${ }^{\# 3}$, \\ Lina Meza-Andrade ${ }^{\# 4}$, Victor Martelo ${ }^{* 5}$ \\ \# University of Guajira, La Guajira, Colombia \\ 1 emunoz@unigajira.edu.co \\ 2 mrmunoz@unigajira.edu.co \\ ${ }^{3}$ katyherrera@unigajira.edu.co \\ ${ }^{4}$ linameza@unigajira.edu.co \\ * Independent researcher, Colombia \\ 5 vmartelog715@hotmail.com
}

\begin{abstract}
The purpose was to develop a theoretical knowledge to the scientific knowledge of the sustainable Eco-Ethnotourism activity tending to minimize the problems of environmental contamination of the study area and the preservation of the Wayuu culture, based on the empirical dynamics of the community. This study was conducted in the Integrated Management District (DMI) delta of the Ranchería-Riohacha River. The results are made up of a project management and planning tool that helps to strengthen conservation and sustainable management actions in the area. The methodology was based on the qualitative approach of [1], [2], using the ethnographic method of [3] and [4], the observation technique, the survey and the semi-structured interview, the environmental and cultural characteristics of the study area, to make a participative diagnosis, definition of the sustainability indicators of the eco-ethnotourism activity in a participative way with the inhabitants, the potential ecoethnotouristic index was established,. It was concluded that there is illegal occupation of the river bank, constructions without planning, pressure of resources, especially of mangroves; there is inter-institutional disarticulation and community, there is no continuity of the plans and programs of the public institutions in charge of the management and preservation of this ecosystem.
\end{abstract}

Keyword - Delta of the Ranchería River, environmental sustainability, environmental management, ethnotourism, eco-tourism.

\section{INTRODUCTION}

Ecotourism and ethnotourism, a duality of specialized tourism that is shared and experienced in the same environment as is the case of La Guajira, which is considered a multi-ethnic and biodiverse department and is enjoyed by the eco and ethno throughout of the department in its unique ecosystems. Starting from this point of view, this study focuses on the development of eco-tourism activity in the delta of the Ranchería River, aimed at improving the environmental quality of the delta and environmental management for the conservation of the ecosystem, which apart from its landscape beauty, is the main habitat that stabilizes and protects that coastal area, contributes to the support of the quality of coastal water and is recognized as a reproduction scenario for many species with commercial importance, such as mammals, birds, reptiles and fish, [5]. In addition to this, it is emphasized that being an ecosystem very affected by anthropogenic activities, [6] the lack of clarity of the interinstitutionality to articulate the environmental in the plans and projects executed in the interest of a possible impact on the conservation of this important ecosystem, with potential impacts on fishing, aquaculture and the infrastructure of coastal communities.

The objective of the research was to propose sustainable eco-ethnotourism in the District of Integrated Management of the delta of the Ranchería River as an environmental management tool that helps to conserve and protect environmental and cultural aspects of the protected area and the improvement of living conditions of the local populations. For this, it was proposed to carry out a participatory diagnosis that considers the environmental and sociocultural aspects of the area. These findings were the subject of study for the proposal of eco-ethnotourism sustainability indicators in order to be used as applicable strategies in the conservation of biodiversity.

The investigation is traced, as a compulsory dynamic before the study of the evidences of the case in the population of the delta of the Ranchería river, since the margin of what has been written and researched in relation to the subject is meager, the hard work that is urged in the research, studies and research conducted by the University of La Guajira, entering the population of the delta Ranchería River, collecting important data on the people, the ecosystem, problems and characteristics, no doubt, are evidences applied as a research reinforcement methodology before the literature review of publications, visits and interviews conducted on the population under study. 


\section{Perspective of the situation}

Colombia is one of the Latin American countries that has a great tourist interest due to its variety of landscapes, large area of coastal areas, cultures, festivities, traditions and folklore, among other attractions. This country biodiverse in its Caribbean region strategically, has one of the departments that in recent years has shown an accelerated tourist growth; this is how in La Guajira, there has been a boom in the development of tourism activities in natural settings, with the largest attraction being the indigenous reservation territory; where these activities are developed without any planning, without control of the negative impacts that are caused to the environment, natural resources and ethnic cultures.

These statements are also corroborated by [7], when they argue that "mangroves are also subject to anthropogenic tensioners, such as deforestation, grazing, the accumulation of solid, organic and inorganic waste, as well as wastewater" (2014, p 40). ), aspects evidenced in the observations and the field work carried out in the DMI of the Ranchería river delta.

\section{TOPICAL CONCEPTIONS OF RESEARCH}

\section{A. Ethnotourism}

In the DMI of the Ranchería delta, the interrelation of the environment with ethnicity and tourism is clearly evident, there being a natural conjugation between the ethnic, the Eco and their relationship with the same environment, it should be noted that when interacting with the population in a direct perspective, this interrelation between nature and community can be perceived in the same space. In ethnoturism, tourists seek to satisfy that need to know those ancestral cultures, within their own paradigm in the search for historical vestiges [8]. Similarly, the development of ethnoturism in a specific territorial space is recognized as an indigenous settlement that according to Ojeda is defined as "the ancestral territory that is constituted in the vital space where the spiritual, social, cultural, economic and political life of the Be Wayuu "(2012, p. 15).

The community settled in the delta of the Ranchería River, is directly related to the biotic environment (we are a single world) that has a richness in florist resources and is the means of subsistence for these communities, nevertheless, it is evident, a relevant ecosystem importance, ecotourism and sociocultural, which is closely related to the socioeconomic aspect of the communities in this area; in view of this repercussion found in the research links, the opportunity for the generation of income in the settlers can be missed, through the hunting of some minor species, fishing and the use of the forest resource.

\section{B. Ecotourism}

[9] Describe ecotourism as a favorite specialty for tourists, seeking the enjoyment of the natural to appreciate and in some cases study the natural attractions and / or cultural manifestation, this tourism modality seeks to promote the conservation of ecosystems and the preservation of the cultures of the tourist destination, with a low environmental and cultural impact, which promotes an active and socioeconomically beneficial involvement.

Ecotourism represents a strategy of benefits for the communities belonging to the population area under study, being, not only an allowed economic activity, but a conservation strategy for ecosystems and / or protected areas with ecotourism vocation, [10]; therefore, the ecotourism exercise implies a cooperation between all the actors involved.

With this conceptual manifestation, a sustainable tourism is sought that allows an enjoyment of the natural goods, knowledge and preservation of the cultural traditions, generating satisfaction and social welfare in the tourist destination [11]; in the ecosystem related to the case of the delta DMI of the Ranchería River, there is a relict of mangroves, which, when viewed from a vulnerability perspective due to its high environmental impact, requires immediate preservation strategies, since the life of this ecosystem is favourable an active and socioeconomically beneficial relationship for local populations, as stated in [12].

\section{The sustainability of eco-ethnotourism}

In recent times, sustainable development is a topic of interest and study in all fields; economic, political, environmental and social; to what [13] it defines as a methodological theoretical foundation that gives rise to studies, economic projects, programs and government plans to promote development.

In this sense, the environmental sustainability of ecosystems is a process of continuous improvement, flexible collective construction and active participation of the various actors involved to enjoy the environmental goods of the present, conserving resources for the enjoyment of future generations reason that eco-ethnotourism is considered an economic activity closely related to the sustainable development of peoples and the conservation and preservation of natural resources, biodiversity, the quality of environmental services, cultural and ethnic identity. 


\section{Integrated management district (DMI)}

According to [14], an Integrated Management District (DMI) is the geographic space, in which landscapes and ecosystems maintain their composition and function, although their structure has been modified, whose associated natural and cultural values are within reach of the human population to use for their sustainable use, preservation, restoration, knowledge and enjoyment. Similarly, in [15] the District of Integrated Management of Renewable Natural Resources is described as a space of the biosphere, which due to environmental or socioeconomic factors, is delimited so that within the criteria of sustainable development it is ordered, planned and regulate the use and management of renewable natural resources and the economic activities that take place there.

\section{METHODOLOGY}

This research has a qualitative approach that, according to [4], is selected when: "It seeks to understand the perspective of the participants (individuals or small groups of people being investigated) about the phenomena that surround them, to deepen their experiences, perspectives, opinions and meanings, that is, the way in which the participants they perceive their reality subjectively. It is also advisable to select the qualitative approach when the subject of the study has been little explored, or has not been done research in a specific social group".

In the same way, the qualitative approach tries to make an approximation of social situations to explore, describe and understand them; based on the knowledge of the people involved in them, this means that individuals interact with other members of their social context, understanding their meaning and knowledge of their reality [1], Thus, taking into account the above, the research sought to analyze facts within the focal community of the Ranchería river delta.

The data collection techniques that were used, focused on investigating the environmental and cultural situation in the communities settled in the area of influence of the DMI of the Ranchería river delta, which focused on the environment - sociocultural factors and which they frame the eco-ethnotourism system of the area.

According to [16], when the research touches the social sphere for obtaining information, the main techniques for gathering qualitative data are observation, the survey, the interview, the focus groups, the collection of documents, materials and the histories of life, which were considered and carried out in the present investigation. Likewise, since the research is focused on an area of social influence, a review of several ethnographic studies was carried out to find patterns, and thus describe the social world as it is continually being constructed, emerging as objective, ordered, intelligible and familiar reality.

The ethnographic perspective, in this type of approach, is relevant in the observations that were made, its study, provided reconstructions in the cultural context, the values, and beliefs of the participants of the Wayuu ethnic group; the researcher was placed in a situation and disposition that allowed to observe the behaviors of the community within the environmental context and tried by all possible means to obtain structures of meanings that testify the social behaviors, in relation to environmental factors that can affect the environment of the community and eco-ethnotourism environmental management of the DMI delta del río Ranchería.

The techniques used to obtain the information were: direct observation of the Villa Fátima neighborhood and the indigenous communities of Pasito and Cangrejito, the visits to the different ranches, the population of the community and specific sites of the delta, surveys conducted at random with 200 families in the community, interviews applied to Wayuu leaders and external experts, talks to target groups of young people and adults, documentary review, life stories and workshops held in concert with the community.

To obtain the information, the survey is divided into three important components that extract specific characteristics of the population, such as: 1) The family component, the information of the nucleus, its location and the level of study; 2) The socioeconomic component, commercial activity for the generation of income; 3) The environmental component, based on the use of ecosystem resources, the characteristics of the dwelling, the behavior of public services and the management of solid and liquid waste.

\section{E. Data collection}

The interview technique was applied to collect information from community leaders and local experts, who were chosen for their knowledge of the culture and environmental dynamics within the community of the Ranchería river delta and external experts, researchers, representatives of public and private entities that are related to the environment; undoubtedly, all the actors with which a margin of direct intervention was established, possessed continuous action on issues of culture and / or tourism and were of a significant nature for the contribution and collection of the different points of view related to the Topics raised from eco-ethnotourism as an option for sustainable environmental management. 
At the same time, we observed the need to conduct a semi-structured interview to determine in advance what is the relevant information that is required; semi-structured interviews are based on a guide of issues or questions and the interviewer is free to introduce additional questions to clarify concepts or obtain more information on desired topics [16]. One of the characteristics of the semi-structured interview is that open questions are asked in it, giving an opportunity to receive more nuances of the answer; it allows to interweave subjects, but it requires a great attention on the part of the investigator to be able to channel the subjects and an attitude of active listening.

Three interview formats were applied, each according to the characteristics of the interviewees; one to local experts, external experts and tourism entrepreneurs.

Another technique, which was implemented, was based on carrying out workshops, such as the Problem Tree, where the causes and effects of the problem presented in the Delta of Ranchería area were identified [17]; the fundamental basis for the development of the participatory diagnosis, where children, youth and adults were clearly outlined the main environmental problems that the inhabitants of the Ranchería delta have in their communities.

The workshops planned, designed, prepared, organized and carried out in the different meetings, were structured as spaces to share and build knowledge scenarios, taking into account the participation of those who with their contributions generated an exchange of experiences between the community and the project of research developed in the study area.

\section{F. Population and sample}

The universe population is La Guajira, which has immersed the enigmatic of its landscapes and Wayuu culture where you can take advantage of all the ecological and the ethnographic potential to develop a sustainable activity; the population under study is constituted by the delta of the Ranchería river with three populations equidistant from the Villa Fátima neighborhood and the indigenous communities El Pasito and Cangrejito. The population sample, are the 200 randomly surveyed families that allowed to collect reliable and direct information to develop an analysis on the population under study.

For the determination of the population, different instruments were used for the data collection, among the most transcendental, the observation, the recording, the anecdotal record, the field diary, the notebook of annotations, the photographic record, the chronogram of activities and the work log.

\section{RESUlts}

In the research, important information was obtained on all the issues raised. Based on this, the analytical and interpretative management was executed in order to develop the research report based on the data obtained, under the following correlated aspects:

It was possible to gather great information provided by the inhabitants of the delta of the Ranchería River during the visits, meetings and interviews conducted; under the bower they could be evidenced by direct contact with the actors involved, a number of significant aspects and great value of the culture, so they were urged towards a compilation of all the information accumulated through the techniques and instruments used throughout the investigation.

The collection of information led to the realization of some concrete and effective activities among which are: The visits, which were made by initial agreement as a measure of cultural respect with some leaders, in order to explain the importance of research. Previous exploratory visits were made, where the environmental, natural and population characteristics found during the first hearing were identified at the start of the experiential investigation. After establishing the first contacts with the traditional authority and obtaining the endorsement of the leaders, the territorial entry to the study area was continued in order to initiate the investigation, establishing the dates and times for the meetings and the respective workshops with the community.

After having the endorsement of the traditional authority and the way leaders, exploratory visits were made where the different situations on the environmental and social aspects were observed, such as: poor vegetation, unpaved streets in the neighborhood of Villa Fátima, grooves of water accumulated after the rains that become decomposed by organic matter, flooding in patios and free spaces taken as a soccer field, housing in various materials, wood, blocks, bricks, mud or clay, garbage, especially plastic bags in the surroundings, empty patios and mountains, bridleways, and mountains of rubble.

\section{A. Expected impact}

The impacts generated by the tourist activity are given by the interaction between the tourist, the ecosystem and the local culture, when the load capacity is exceeded and becomes a nuisance for both the visitor and the target population. In the last four decades, tourism has grown rapidly and the number of tourist destinations to visit has increased [18], increasing with them the impacts on the environment, economic and social-cultural aspects. 
The reflection made on what was found is evident in the research process framed in eco-ethnotourism in the integrated delta management district of the Ranchería River, La Guajira: an option of sustainable environmental management, has characteristics that led to a learning and appropriation of knowledge for the description and analysis of the information obtained according to the nature of the research, where a process was conceived and conceived with the which was determined the type of research to be used, having a clear focus that led to the design of the investigation, throwing today a series of concrete results as a result of the whole investigative process.

In this reflection, it can be seen that based on the results obtained, a clear and evident corollary was generated, which gave rise to a participatory diagnosis, which served as a study material to define the sustainability indicators and thus determine the eco-ethnotouristic potential of the delta of the ranchería river.

\section{B. Environmental impact}

Conventional tourism can generate negative impacts such as the loss or destruction of ecosystems due to the massive presence of visitors and the need of tourism entrepreneurs to expand areas for hotels, and other infrastructure, the need to use more resources such as water for the daily hotel service or entertainment infrastructure such as swimming pools, the consumption of food and beverages that generates a large amount of solid and liquid waste; also the means of transport used.

The generation of social and environmental impact, whether positive or negative will depend on the quality of planning that is implemented, which should include the multiple dimensions included in tourism development. The ideal is that the impact is positive, the beneficial effects of tourism for culture and the environment arise when considering that tourism is based on the use and conservation of natural and cultural heritage [19]; meaning for the tourist destination improvements in economic, sociocultural and environmental conditions. In the last four decades, tourism has grown rapidly and tourist destinations have diversified [18], increasing the impact on the environment.

With specialized tourism, such as ecotourism, tourists are attracted by the enjoyment of nature as birds, rivers, lush vegetation; where the environmental impact tends to be positive because the tourist delights in the natural beauty of the place; however, with the increase in the number of tourists, ecosystems tend to be vulnerable due to the continuous presence of visitors and the use of resources, that is, their greater margin of affectation is evident when the carrying capacity of the population is exceeded area (tourist destination). The way to create tourism by the producer is carried out quite often through personal development ("Encounter of two traditions") [20].

\section{Socioeconomic impact}

The socioeconomic impact is evident from the development of tourism, it begins to generate a pool of offers in services aimed at the satisfaction and enjoyment of tourists, in order to boost investment and promote job creation. In the delta DMI of the Ranchería River, the eco-ethnotourism activity would generate an economic impact, both in the tour operators and in the inhabitants of the area; this economic scenario would represent a margin of profitability for the way people, since they increase the sales margin of their handicrafts, offer their services such as attention in the rancherías, ranchería evenings where they make cultural samples of their traditions, myths and legends, with its lodging, guiding, hiking and traditional gastronomy are provided.

It is important to point out that with the development of the eco-tourism activity significant income would be generated for the continuous improvement of the local economy, which in turn would contribute to the increase of district revenues.

\section{Sociocultural impact}

To talk about social-cultural impacts, it is important to review a series of variables such as the number of days the visitor visits, their route through the protected area, the ecological fragility of the system and the type and behavior of the users; in order to be able to determine, the sociocultural impact generated by tourism in the areas determined as a tourist destination, [21]. Table 1 shows the impacts of eco-ethnotourism. 
TABLE I. Impacts of Eco-ethnotourism

\begin{tabular}{|c|c|c|}
\hline & POSITIVE IMPACTS & NEGATIVE IMPACTS \\
\hline \multirow{4}{*}{ SOCIOECONOMIC } & Employment generation & $\begin{array}{c}\text { Only unqualified jobs are linked in } \\
\text { the community }\end{array}$ \\
\hline & $\begin{array}{c}\text { Creation of new productive } \\
\text { opportunities }\end{array}$ & It endangers local products \\
\hline & Economic income of families & Sales at very low costs \\
\hline & Development of communities & $\begin{array}{c}\text { Income of foreigners to handle the } \\
\text { autochthonous }\end{array}$ \\
\hline \multirow{4}{*}{ SOCIOCULTURAL } & Valorization of cultural heritage & $\begin{array}{c}\text { Deterioration of the cultural } \\
\text { heritage of the area }\end{array}$ \\
\hline & Permanence of cultural identity & $\begin{array}{l}\text { Social problem, drug addiction, } \\
\text { prostitution, family uprooting, } \\
\text { imitation of the other. }\end{array}$ \\
\hline & Cultural exchange & $\begin{array}{l}\text { Deculturation and acculturation in } \\
\text { the tourist destination }\end{array}$ \\
\hline & Modernization of culture & $\begin{array}{l}\text { Local realities are distorted and } \\
\text { they imitate the other culture }\end{array}$ \\
\hline \multirow{3}{*}{$\begin{array}{l}\text { ENVIRONMENTAL } \\
\text { IMPACT }\end{array}$} & $\begin{array}{l}\text { Rational use of natural } \\
\text { resources }\end{array}$ & Saturation of strategic ecosystems \\
\hline & Conserve ecosystems & $\begin{array}{c}\text { Loss of productive capacity of } \\
\text { local communities }\end{array}$ \\
\hline & $\begin{array}{l}\text { Restoration of habitats, } \\
\text { preservation of natural parks }\end{array}$ & $\begin{array}{l}\text { Excessive consumption of natural } \\
\text { resources }\end{array}$ \\
\hline
\end{tabular}

\section{Final Thoughts}

After carrying out the present investigation, it was possible to affirm by way of conclusion that there is an illegal occupation of the Ranchería river bank in the delta, which constitutes a socio-environmental and security problem caused by displacement, as well as problems of drug addiction, to which the district administration must implement strategies for the recovery of the eco-tourism path.

Likewise, it was observed that there is an inter-institutional disarticulation and community, each entity has its projects, its programs, there is no continuity of the plans and programs of the public institutions in charge of the management, nor the preservation of species together with the ancestral community settled in the delta del Rio Ranchería.

Finally, it was observed that the communities settled in the delta of the Ranchería River: Villa Fátima, Cangrejito and El Pasito have an organization and articulation of programs, government plans to carry out environmental and cultural processes conducive to the improvement of the quality of life of the settlers

\section{REFERENCES}

[1] E. Bonilla, Más allá del dilema de los métodos. Bogotá, Colombia: Editorial Norma, 2005.

[2] J. Martínez, M. pascual, J. Anguerra, R. Ato and G.Vallejo, Metodología de la investigación psicológica, in M. T. Métodos de investigación en psicología, pp. 23-43, Síntesis: Madrid, $1995 . \quad$ Available: http://www.cepsifotocopiadora.com.ar/archivos/folios/31741_201592.pdf

[3] R. Guber, La etnografía. Método, campo y reflexibilidad. Bogotá: Grupo editorial Norma, 2011. Available: https://jalintonreyes.files.wordpress.com/2011/05/guber-rosana-la-etnografia.pdf

[4] R. Hernández, C. Fernández and P. Baptista, Metodología de la investigación, 6th edition. Mc Graw Hill, 2014.

[5] Corporación autónoma regional de La Guajira -Corpoguajira, Acuerdo Nº 015 de 13 de noviembre de 2014. 2014.

[6] N. Rangel, "Contribución antropogénica a los cambios geomorfológicos y evolución reciente de la costa Caribe Colombiana," Universidad Nacional de Colombia Gestión y Ambiente, vol. 12, no. 2, pp. 43-56, 2009.

[7] M. Castellanos and A. Carabalí, El delta del Rio Ranchería, una mirada biofísica y social antes de la represa. Barranquilla, Colombia: Tonos Editorial del caribe, 2014.

[8] I. González, "Van Rensselaer Potter y Edgar Morin: Cambios en el pensamiento ético contemporáneo," Rev. latinoam. bioet, vol. 12, no. 1, 22 edition, pp. 46-61, 2012.

[9] H. Ceballos-Lascuráin, Tourism, ecotourism and protected areas; the state of nature-based tourism around the world and guidelines for its development. Switzerland: Gland, 1998.

[10] Sistema De Parques Naturales Nacionales De Colombia, Guía para la planificación del ecoturismo en parques nacionales naturales de Colombiak. Bogotá, 2013.

[11] J. Gutiérrez, Ecoturismo comunitario. Turismo Rural Bolivia Plaza Venezuela (El Prado), 2001.

[12] Ministerio de comercio, industria y turismo, Política para el desarrollo del ecoturismo, Dirección de Turismo. Ministerio de ambiente vivienda y desarrollo territorial. Unidad Administrativa Especial del Sistema de Parques Nacionales Naturales República De Colombia, 2003. 
[13] S. Guzmán, "Los Dilemas del Desarrollo Sustentable: Limitantes para alcanzar el desarrollo sustentable en Tijuana," El bordo, vol. 5, no. 3, pp. 15-36, 2010.

[14] Unión Internacional para la Conservación de la Naturaleza (UICN), Acuerdo de Conservación de Naturaleza y Recursos Naturales, 1991.

[15] Decreto 1974 de 1989. Article no. 2. Presidency of the Republic of Colombia, Bogotá, 1989.

[16] R. Hernández, C. Fernández and P. Baptista, Metodología de la investigación. México: Mc Graw Hill, 2010.

[17] F. Geilfus, 80 herramientas para el desarrollo participativo: diagnóstico, planificación, monitoreo, evaluación, San José, Costa Rica, 2001

[18] J. Quintero, Los impactos económicos, socioculturales y medioambientales del turismo y sus vínculos con el turismo sostenible. Universidad complutense de Madrid, Anuales del museo de América, 2004.

[19] P. Pires, Turismo e meio ambiente: relação de interdependência, in Phillipi Jr, A. \& Ruschmann, D. V. de M. (Editors)Gestão ambiental e sustentabilidade no turismo, pp. 3-29, 2010.

[20] E. Ortega, Investigación y estrategias turísticas. Madrid, España: Thomson Editores Spain, 2003.

[21] M. Blanco, Guía para la Elaboración del Plan de Desarrollo Turístico de un Territorio. San José, Costa Rica: Instituto Interamericano de Cooperación para la Agricultura -IICA, 2007.

\section{AUTHOR PROFILE}

Emérita Sofía Muñoz Estrada works as part-time professor in the University of La Guajira (Colombia). Mrs. Muñoz completed his magister from University of Cordoba (Colombia). Mrs. Muñoz completed his undergraduate in Bachelor in preschool at the University Antonio Nariño University.

Mirian Muñoz Estrada works as part-time professor in the University of La Guajira (Colombia). Mrs. Muñoz completed his magister from University of La Guajira (Colombia). Mrs. Muñoz completed his undergraduate in Environment Engineering at the University of La Guajira.

Katy Herrera works as part-time professor in the University of La Guajira (Colombia). Mrs. Herrera completed his magister from University of La Guajira (Colombia). Mrs. Herrera completed his undergraduate in Systems Engineering at the Autonomous University of the Caribbean.

Lina Meza-Andrade works as part-time professor in the University of La Guajira (Colombia). Mrs. MezaAndrade completed his magister from University of La Guajira (Colombia). Mrs. Meza-Andrade completed his undergraduate in Systems Engineering at the Autonomous University of the Caribbean.

Victor Martelo Gómez works as independent researcher (Colombia). Mr. Martelo completed his undergraduate in Psychology at the San Buenaventura University. 